\title{
HARMONISASI KERAGAMAN DALAM KOMUNITAS MEDITASI KESADARAN DI WIHARA MENDUT
}

\author{
Waluyo \\ Sekolah Tinggi Agama Buddha Negeri Sriwijaya \\ waluyo.stabn.sriwijaya@gmail.com
}

\begin{abstract}
Abstrak
Penelitian ini bertujuan untuk mendeskripsikan keharmonisan dalam keragaman komunitas Meditasi Kesadaran di Wihara Mendut. Komunitas Meditasi Kesadaran di Wihara Mendut memiliki anggota dan simpatisan yang terdiri dari beragam latar belakang orientasi spiritual dan agama; di samping pelaksanaan retret yang sudah dilaksanakan puluhan tahun, serta telah menyebar ke berbagai daerah. Relevansi meditasi dengan permasalahan kehidupan, dampak meditasi, dan makna keberagaman bagi peserta retret diperlukan deskripsi komprehensif melalui studi mendalam agar diperoleh gambaran menyeluruh mengenai karakteristik komunitas Meditasi Kesadaran.

Penelitian ini menggunakan pendekatan case study karena memandang peserta retret meditasi kesadaran di Wihara Mendut sebagai kesatuan kelompok, yang mana anggota yang terlibat sebagai subjek penelitian mewakili dan mencerminkan dirinya sendiri sebagai informan. Jenis case study yang digunakan bersifat interpretatif dan kritis, yaitu memahami suatu fenomena melalui pemaknaan dari orang-orang yang terlibat di dalamnya, sekaligus melakukan refleksi kritis terhadap praktik-praktik yang sedang terjadi dan asumsi dasar yang biasanya diterima apa adanya. Subjek penelitian adalah peserta retret Meditasi Kesadaran yang dilaksanakan di Wihara Mendut, Magelang, Jawa Tengah. Objek penelitian adalah keragaman orientasi spiritual peserta retret yang dijelaskan dalam tiga tema yaitu relevansi meditasi dengan permasalahan kehidupan, dampak meditasi bagi peserta retret, dan makna keberagaman dalam komunitas Meditasi Kesadaran di Wihara Mendut. Teknik pengumpulan data menggunakan nontes melalui observasi, wawancara, dan dokumentasi dengan instrumen berupa pedoman observasi, pedoman wawancara, dan dokumen pendukung terkait lainnya. Keabsahan data menggunakan uji kredibilitas, transferabilitas, dependabilitas, dan konfirmabilitas. Data dianalisis menggunakan model Miles \& Huberman yang terdiri dari pengumpulan data, reduksi data, penyajian data, dan penarikan kesimpulan.

Hasil penelitian menunjukkan bahwa: (a) relevansi meditasi dengan permasalahan kehidupan bagi peserta retret meditasi kesadaran di Wihara Mendut berkaitan erat dengan permulaan peserta mengenal meditasi, perbandingan antarguru, tahapan pencarian, kemampuan mengidentifikasi permasalahan kehidupan dan problematika dalam mengikuti meditasi
\end{abstract}


kesadaran, dan saran bagi penyelenggara dalam mendukung pelaksanaan meditasi; (b) dampak meditasi dalam kehidupan sehari-hari bagi peserta retret meliputi bentuk latihan, jadwal dan waktu latihan, cara menanggapi situasi, pemahaman yang lebih tinggi dalam meditasi kesadaran, persyaratan berlatih, makna dampak bagi peserta, dan hasil meditasi; dan (c) pandangan peserta retret meditasi kesadaran memiliki kaitan erat dengan ketaatan dalam mengikuti retret, hubungan sesama peserta, cara pandang terhadap agama lain, hakikat keberagaman, dan keberlanjutan komunitas di masa mendatang.

Kata kunci: Meditasi kesadaran, keragaman, harmonisasi, Wihara Mendut.

\section{Pendahuluan}

Dunia berkembang mengikuti zaman yang terus bergerak seiring dengan perubahan peradaban manusia. Perubahan zaman ditandai dengan kemajuan di segala bidang, baik materiel maupun imateriel. Kemajuan tersebut menuntut manusia untuk menyesuaikan dirinya agar segala perilaku sesuai dengan unsur moral atau etika, baik secara filosofis maupun teknis mekanis. Saat ini, peradaban manusia berada pada industri serba digital sebagai konsekuensi dari kemajuan yang terus-menerus berkembang. Sebagai ilustrasi, pada saat yang sama, informasi yang dikirim oleh seseorang dari belahan dunia satu dapat diketahui oleh seseorang lainnya di belahan dunia yang berbeda. Penyesuaian diri ini diperlukan agar manusia mampu bertahan dan memiliki daya juang tangguh dalam menghadapi berbagai fenomena kehidupan. Fenomena kehidupan, baik suka maupun duka, dipuji atau dicela, untung-rugi, sehat-sakit; segala bentuk permasalahan kehidupan sebagai kontak diri dengan sosialnya, di samping sebagai konsekuensi kehidupan itu sendiri; juga dapat disebabkan oleh respons individu terhadap dunia di sekelilingnya. Kondisi psikologis seseorang dalam menghadapi fenomena kehidupan dan kemajuan zaman melahirkan orientasi baru dalam spiritual, jika tidak ingin disebut sebagai agama baru dalam arti yang lebih luas.

Orientasi spiritual manusia modern berkembang seiring dengan adanya berbagai masalah kehidupan yang perlu dicarikan solusinya dari setiap individu yang mengalaminya. Meditasi menjadi laku spiritual yang banyak dicari oleh orang yang sedang menghadapi masalah. Hal ini tidak berarti bahwa meditasi baru akan dilakukan jika seseorang mempunyai masalah kehidupan. Banyak orang melakukan meditasi justru dalam rangka menyiapkan batin dan mentalnya, jika suatu saat nanti di masa depan menghadapi berbagai masalah yang tidak dapat dielakkan. Meditasi menjadi gaya hidup manusia modern dengan berbagai alasan. Berbagai macam teknik berkembang di seluruh dunia dan diajarkan oleh banyak guru dengan berbagai latar belakang, baik dari sisi keilmuan, praktisi, maupun budaya. Pelatihan dan retret meditasi diselenggarakan oleh berbagai pihak dan elemen masyarakat dengan latar belakang beragam untuk memenuhi 
banyaknya permintaan dan kecenderungan gaya hidup baru dalam hal spiritualitas. Dengan kata lain, kelas-kelas meditasi menjamur diselenggarakan dengan berbagai tujuan, spesifikasi tertentu, teknik, guru; yang pada dasarnya sebagai cermin new lifestyle dunia modern. Gaya hidup baru ini dapat menimbulkan pengaruh bagi kehidupan, baik diri sendiri maupun masyarakat secara luas. Pengaruh yang ditimbulkan dapat positif atau negatif sesuai dengan akibat yang ditimbulkannya. Jika gaya hidup meditasi dari individu dibarengi dengan perubahan sosial ke arah yang lebih baik, maka pengaruh positif dapat ditindaklanjuti dengan aksi-aksi nyata yang relevan. Sebaliknya, jika gaya hidup meditatif seseorang menjadikan dirinya sombong, diskriminatif, arogan, intoleran, maka pengaruh negatif gaya hidup ini jelas destruktif yang akan merusak masyarakat secara perlahan. Meditasi sebagai gaya hidup tidak menutup kemungkinan justru jadi jebakan baru dalam pengelolaan batin, alih-alih mental menjadi berkembang tetapi malah terperosok pada hegemoni meningginya keakuan, kecongkakan, dan klaim kebenaran yang berujung pada tindakan diskriminatif dan intoleransi.

Banyaknya laku spiritual meditatif tidak diimbangi dengan pemaknaan yang benar dan mendalam, sehingga menimbulkan ekses negatif bagi komunitas yang benar-benar menegakkan spirit spiritualisme bagi komunitasnya. Kasus penyelenggaraan retret meditasi massal demi target peserta, timbulnya komodifikasi pelatihan, bahkan terjadinya pelecehan seksual yang dilaporkan oleh peserta meditasi merupakan sebagian kecil kejadian yang terjadi pada tempat-tempat retret meditasi. Reputasi buruk retret meditasi menjadi permasalahan bagi penyelenggara yang benar-benar akan memberikan layanan spiritual di bidang ini. Hal-hal negatif dapat terjadi bahkan pada dunia spiritual yang dianggap memiliki kerentanan kecil perilaku yang dianggap menyimpang oleh norma sosial. Di sisi lain, peserta menuntut penyelenggara retret meditasi berlaku baik dan profesional dalam pelayanannya, sedangkan spirit dilaksanakannya meditasi berbasis layanan sosial spiritual nirlaba dan semangat saling membantu antarrelawan. Social worker menjadi jiwa relawan dalam memberikan pendampingan bidang spiritual bagi orang yang membutuhkan. Wihara memiliki peran besar dalam menumbuhkan semangat ini sebagai bentuk tanggung jawab sosial yang nyata untuk mengimplementasikan Dharma agar membumi dan sesuai konteksnya.

Konsep meditasi diklaim ada di setiap agama besar dunia. Walaupun meditasi cenderung sebagai ikon Buddhisme, namun agama-agama besar mengenal meditasi dengan berbagai istilah, di antaranya Islam mengenal zikir, Hindu mengenal pranayama dhyana, Kejawen mengenal semedi, Katolik dan Kristen melaksanakan doa meditasi melalui kontemplasi. Agama-agama besar maupun penghayat kepercayaan lainnya yang tersebar di Nusantara kemungkinan memiliki teknik meditasi sendiri-sendiri dalam laku spiritual sebagai bagian dari ajaran yang dianutnya. Meditasi dijalankan sebagai ajaran 
yang melengkapi ritus keagamaan dalam pemahaman agama yang lebih tinggi. Meditasi dijalankan oleh pemeluk agama sebagai penyeimbang ketenangan dalam menjalani masalah kehidupan. Meditasi diyakini sebagai ajaran dalam suatu agama yang penting untuk dipraktikkan dalam mencapai tingkat spiritual yang lebih tinggi, di samping ritual, syariat, tarekat, atau laku peribadahan lain yang bersifat formal materiel. Meditasi dipandang sebagai puncak ritual dalam menjalankan suatu ajaran yang menjadi pedoman hidup seseorang. Meditasi berdampak positif bagi perkembangan batin seseorang yang memiliki cita-cita luhur dalam kehidupan.

Wihara Mendut sebagai salah satu rumah ibadah bagi umat Buddha yang terletak berdekatan dengan Candi Borobudur, Magelang, memiliki program meditasi bagi orang yang memiliki kecenderungan dalam pencarian spiritual dari berbagai kalangan, tidak diperuntukkan bagi umat Buddha saja, yang dikenal dengan Meditasi Kesadaran. Meditasi yang diselenggarakan oleh Wihara Mendut sudah berlangsung puluhan tahun berlangsung dimulai sejak tahun 2000an awal. Awalnya program ini disebut dengan "Meditasi Mengenal Diri" dengan pembimbing Bapak Hudoyo Hupudio, kemudian berganti menjadi "Meditasi Kesadaran" setelah digantikan oleh pembimbing lain, yaitu Bhikkhu Santacitto. Program ini semakin hari semakin banyak diikuti oleh orang dari komunitas non-Buddhis yang cukup beragam, dari sisi perbedaan agama, orientasi spiritualitas, daerah maupun etnis. Tanggapan non-Buddhis terhadap pelaksanaan meditasi di Wihara Mendut beragam, kebanyakan cenderung menyukai dan menganggap unik serta bermanfaat untuk kehidupan sehari-hari dalam menghadapi berbagai masalah kehidupan. Keharmonisan hubungan antarpeserta meditasi berlanjut dalam kehidupan bermasyarakat. Berbagai kegiatan dilakukan dalam rangka reuni atau berkumpul sesama peserta meditasi, bahkan membentuk komunitaskomunitas kecil di daerah masing-masing. Eksistensi mereka ada walaupun dari latar belakang agama yang berbeda. Komunitas-komunitas kecil di daerah tersebut menjadi pemasok peserta meditasi jika di Wihara Mendut akan diselenggarakan retret. Peserta yang dipasok oleh komunitas kecil daerah ini merupakan peserta baru atau juga peserta lama yang ingin mengikuti retret lagi di Wihara Mendut.

Meditasi yang diajarkan berafiliasi dengan teknik meditasi Buddhis yang memiliki spesifikasi pada proses menyadari fenomena baik fisik maupun batin secara objektif. Meditasi jenis ini disebut dengan meditasi vipassana, atau sering dikenal meditasi kesadaran. Program dan komunitas yang dijadikan objek penelitian ini sekaligus sebagai subjek komunitasnya, yaitu Meditasi Kesadaran ("MK"). Program ini dilaksanakan di Wihara Mendut selama empat kali tiap tahun, namun sekarang menjadi dua kali per tahun karena alasan kesibukan dan jadwal yang padat dari pembimbing. Namun demikian, komunitas yang berasal dari berbagai daerah begitu antusias begitu diumumkan pelaksanaan meditasi di Wihara Mendut. 
Perbedaan latar belakang peserta atau anggota komunitas Meditasi Kesadaran menunjukkan relasi sosial yang tidak dapat dipungkiri sebagai bentuk interaksi sosial yang mengeratkan karena memiliki arah spiritualitas yang sama, yaitu meditasi. Namun jika dilihat secara sekilas, penampilan masing-masing individu berasal dari agama yang berbeda, di antaranya Islam, Katolik, Kristen, Hindu, Buddha, Konghucu, agnostik, spiritualis, universalis, bahkan ateis. Perbedaan ini tidak menjadi persoalan di antara mereka yang ditunjukkan dengan orientasi spiritualitas yang sama. Dengan kata lain, pembicaraan mengenai agama hampir tidak pernah mengemuka di antara mereka. Pengelola mengetahui jika agama peserta berbeda satu dengan lainnya dari isian kolom agama pada formulir pendaftaran. Perbedaan agama pada komunitas ini mencerminkan keharmonian dalam masyarakat. Harmonisasi komunitas Meditasi Kesadaran tentu saja dipengaruhi oleh banyak faktor, salah satunya adalah kecenderungan dan orientasi yang sama terhadap spiritualitas dalam bentuk meditasi.

Peneliti tertarik mendeskripsikan harmonisasi komunitas "MK" yang memiliki keberagaman dari banyak segi di Wihara Mendut. Penelitian ini diharapkan memberikan manfaat utama dalam mendeskripsikan harmonisasi masyarakat yang memiliki perbedaan guna mencapai tatanan kehidupan sosial yang saling menghormati.

Identifikasi masalah dilakukan untuk memberikan gambaran dengan jelas segala sesuatu yang menjadi problematika atau kebergantungan antarmasalah yang turut menjadi sebab atau sebagai akibat dari permasalahan yang menjadi fokus dalam penelitian ini. Beberapa masalah yang dapat diidentifikasi pada penelitian ini, yaitu: (a) perubahan zaman dan peradaban menuntut manusia menyesuaikan diri dengan dinamika dunia dan kemajuannya terutama pada sisi mental spiritual agar mampu bertahan menghadapi situasi sulit yang menghimpit; (b) banyaknya permasalahan kehidupan yang dihadapi oleh setiap orang sebagai akibat kemajuan zaman, yang cenderung direspons berlebihan dengan dalih pertahanan dan aktualisasi diri yang berpotensi pada ketidakharmonisan; (c) munculnya berbagai komunitas spiritual dalam laku meditatif yang berdampak pada banyaknya pilihan, namun tidak diimbangi dengan pemaknaan mendalam tetapi sekadar mengikuti gaya hidup dan hiburan spiritual; (e) penyelenggaraan retret meditasi di Wihara Mendut telah berlangsung puluhan tahun, bahkan terbentuk komunitas yang memiliki budaya bersama tersebar di berbagai kota, namun belum ada studi komprehensif mengenai kelompok tersebut; dan (f) komunitas Meditasi Kesadaran di Wihara Mendut berasal dari beragam latar belakang, di antaranya etnis, daerah, pekerjaan, peran sosial, dan agama; namun memiliki hubungan harmonis dalam budaya bersama meditatif yang cenderung dijadikan sebagai laku keseharian; namun belum diketahui apakah perilaku meditatif tersebut terinspirasi dari komunitas atau tidak; sehingga memerlukan kajian mendalam melalui penelitian. 
Rumusan masalah dalam penelitian ini adalah bagaimanakah keharmonisan dalam keragaman komunitas "Meditasi Kesadaran" di Wihara Mendut? Rumusan masalah tersebut diturunkan menjadi pertanyaan penelitian, yaitu (a) bagaimanakah relevansi meditasi dengan permasalahan kehidupan yang dihadapi oleh peserta pada komunitas Meditasi Kesadaran?; (b) bagaimanakah dampak meditasi dalam kehidupan sehari-hari yang dirasakan oleh peserta meditasi pada komunitas Meditasi Kesadaran?; dan (c) bagaimanakah komunitas Meditasi Kesadaran di Wihara Mendut memandang keberagaman orientasi spiritual peserta?

Meditasi menurut konsep Buddhis terdiri dari dua kategori, yaitu samatha bhavana dan vipassana bhavana. Vipassana bhavana merupakan praktik meditasi yang lebih berorientasi pada pengamatan objek fisik maupun batin sebagaimana adanya. Tujuan vipassana bhavana yaitu mengembangkan batin mengarah pada pencapaian pencerahan terhadap fenomena kehidupan yaitu dukkha, anicca, anatta. Ketiga fenomena tersebut menjadi ciri khas kehidupan yang terkondisi akan mengalami penderitaan, ketidakkekalan, dan tanpa adanya inti yang kekal.

Secara alamiah, manusia mengalami perkembangan batin atau sering disebut dengan perkembangan rohaniah. Perkembangan batin manusia mengarah pada kedewasaan yang secara lahiriah (jasmani) dapat dilihat dari umur kronologis. Namun demikian, bertambahnya umur seseorang tidak secara otomatis bertambah pula kebijaksanaan atau kedewasaannya. Kemampuan yang dapat dicapai oleh seseorang dalam perkembangan batin mencerminkan kematangan orang tersebut. Orang yang memiliki kematangan batin memiliki pengalaman keagamaan yang didapatkan dari keluarga dan lingkungannya. Pengalaman keagamaan merujuk pada perasaan yang muncul dalam diri seseorang setelah menjalankan ajaran agama. Kemampuan seseorang untuk mengenali atau memahami nilai ajaran agama atau nilai-nilai luhur ajaran agamanya serta menjadikan nilai-nilai tersebut dalam bersikap dan bertingkah laku merupakan ciri orang yang memiliki kematangan beragama.

Penelitian Kumbang Sigit Priyoaji (2017) tentang "Bimbingan Meditasi Zen dan Implikasinya terhadap Kesehatan Mental: Studi atas Kelompok Meditasi Zen di Wihara Buddha Prabha Gondomanan Yogyakarta" menemukan bahwa motivasi peserta retret meditasi memerlukan perubahan dalam diri agar lebih baik, terutama akan kebutuhan spiritual yang mengarah pada ketenangan jiwa. Hasil penelitian juga menyimpulkan bahwa peserta merasakan berbagai sensasi kondisi tubuh yang diharapkan nantinya mampu mengembangkan jiwa yang tenang. Di samping itu, sebagai dampak dari pelaksanaan meditasi Zen ini, peserta merasakan adanya harapan untuk dapat mencapai ketenangan dari masalah yang dihadapi dalam hidup dengan lebih bisa menerima keadaan dan kenyataan yang ada. Penelitian Kumbang Sigit Priyoaji sejalan dengan penelitian yang akan dilakukan, terutama pada metode kualitatif yang digunakan dan keberagaman peserta yang mengikuti 
retret meditasi. Hasil penelitian ini memiliki unsur transferabilitas yang selaras dengan penelitian yang akan dilakukan. Dengan kata lain, penggunaan hasil penelitian ini diterapkan pada penelitian yang akan dilakukan, khususnya pada penggalian informasi yang lebih mendalam dan observasi partisipatif.

Penelitian Harmilah, Elly Nurachmah, \& Dewi Gayatri (2011) mengenai "Penurunan Stres Fisik dan Psikososial Melalui Meditasi pada Lansia dengan Hipertensi Primer" yang menggunakan desain kuasi eksperimen menunjukkan penurunan stres fisik dan psikososial setelah meditasi pada kelompok intervensi lebih banyak dibanding dengan kelompok kontrol. Berdasarkan penelitian ini, meditasi dapat menurunkan stres fisik dan psikososial pada lansia dengan hipertensi primer secara signifikan. Penelitian ini sejalan dengan penelitian yang akan dilakukan, terutama pada alasan peserta meditasi yang mengikuti retret biasanya bermula dari pengalaman diri yang mengalami stress mental, depresi, dan cemas. Namun demikian, penelitian ini memiliki perbedaan dengan penelitian yang dilakukan yang menggunakan pendekatan kualitatif untuk memberikan makna mendalam terhadap objek penelitian, yaitu meditasi. Di samping itu, penelitian yang akan dilakukan lebih berfokus pada beragamnya usia peserta, bahkan terdapat anak dan remaja yang mengikuti retret meditasi pada komunitas Meditasi Kesadaran, tidak hanya lansia saja.

Penelitian Sekar Ayu Aryani (2015) yang berjudul "Orientasi, Sikap, dan Perilaku Keagamaan: Studi Kasus Mahasiswa Salah Satu Perguruan Tinggi Negeri di DIY)" menemukan tiga kategori orientasi keagamaan mahasiswa, yaitu liberal, fundamental, dan moderat. Orientasi keagamaan seseorang menjadi dasar berperilaku dalam keseharian, terutama saat berinteraksi dengan sosial masyarakat. Masyarakat terdiri dari beragam individu yang memeluk agama sebagai pedoman hidupnya, yang mana interpretasi terhadap nilai-nilai ajaran agamanya terwujud dalam interaksi dengan sesamanya. Penelitian ini berfokus tanggapan peserta meditasi tentang perilaku intoleransi sebagai dampak pemahaman agama yang cenderung destruktif bagi pihak lain. Penelitian yang dilakukan oleh Sekar Ayu Aryani menjadi dasar penggalian informasi kepada informan dalam hal perilaku intoleransi yang semakin marak jika kematangan beragama dan laku spiritual dikesampingkan oleh setiap individu.

\section{Metode}

Penelitian kualitatif ini menggunakan pendekatan case study karena berfokus pada satu unit kelompok tertentu (Saldaña, 20ll: 8). Peserta meditasi retret kesadaran di Wihara Mendut dipandang sebagai kesatuan kelompok yang diteliti, di mana anggota yang terlibat sebagai subjek penelitian mewakili dan mencerminkan dirinya sendiri sebagai informan. Selain menggunakan case study yang bersifat interpretatif karena berusaha memahami suatu fenomena melalui pemaknaan dari orang-orang yang 
terlibat di dalamnya, penelitian ini juga menerapkan critical case study untuk melakukan refleksi kritis terhadap praktik-praktik yang sedang terjadi dan asumsi dasar yang biasanya diterima apa adanya (Myers dalam Samiaji Sarosa, 2012: 115). Penelitian ini bermaksud memahami makna meditasi kesadaran bagi peserta retreat yang dilaksanakan di Wihara Mendut.

Penelitian ini dilaksanakan di Wihara Mendut sebagai penyelenggara retreat meditasi kesadaran yang dilaksanakan sejak tahun 2000an hingga sekarang. Informan ditelusuri melalui kontak grup atau didatangi langsung untuk diwawancara, di samping sebagian peserta memang mengikuti retreat secara rutin tiap tahun yang diselenggarakan empat kali dan kini dua kali.

Subjek penelitian adalah peserta retreat meditasi kesadaran dan penyelenggara. Objek penelitian adalah keragaman orientasi spiritual peserta retret yang dijelaskan dalam tiga tema yaitu relevansi meditasi dengan permasalahan kehidupan, dampak meditasi bagi peserta retret, dan makna keberagaman dalam komunitas Meditasi Kesadaran di Wihara Mendut.

Berdasarkan kepentingan menangkap makna secara tepat, cermat, rinci, dan komprehensif, pengumpulan data dalam penelitian ini dilakukan melalui observasi, wawancara, dan dokumentasi. Menurut Mills (Haris Herdiansyah, 2013: 131) observasi merupakan kegiatan yang terencana dan terfokus untuk melihat dan mencatat serangkaian perilaku ataupun jalannya sebuah sistem yang memiliki tujuan tertentu, serta mengungkap apa yang ada di balik munculnya perilaku dan landasan suatu sistem tersebut. Teknik observasi digunakan untuk mengamati, mengumpulkan data, dan mendeskripsikan tentang kondisi Wihara Mendut, aktivitas pelaksanaan retreat meditasi kesadaran, dan sarana prasarana yang ada. Pengamatan dimulai dari pengamatan menyeluruh kemudian dilanjutkan dengan pengamatan terfokus. Pengamatan menyeluruh dilakukan untuk mendapatkan catatan lapangan guna menjawab pertanyaan umum mengenai kondisi lingkungan Wihara Mendut sebagai tempat pelaksanaan meditasi kesadaran. Pengamatan terfokus dilakukan untuk menjawab pertanyaanpertanyaan tentang satuan pengalaman yang lebih detail, rinci, dan menggambarkan informasi yang lebih spesifik tentang keterkaitan lokus penelitian dengan fokus penelitian yang dijadikan objek. Pengamatan yang dilakukan dalam penelitian ini adalah pengamatan berperan serta. Pengamatan berperan serta menceritakan kepada peneliti apa yang dilakukan oleh informan dalam situasi peneliti memperoleh kesempatan mengadakan pengamatan. Pengamatan berperan serta dalam penelitian ini terutama pada aktivitas pelaksanaan meditasi kesadaran di Wihara Mendut.

Wawancara digunakan untuk menggali data secara mendalam terhadap kebermaknaan semua aspek yang relevan dengan penelitian menurut persepsi informan. Proses kegiatan wawancara dilakukan dengan terlebih dahulu mempersiapkan pedoman wawancara dengan pertanyaan terbuka, di mana instrumen ini hanya digunakan sebagai arah wawancara yang terfokus pada masalah. Oleh karena itu, penggunaannya tidak dilakukan 
secara ketat, artinya pertanyaan dapat berkembang sesuai dengan jawaban informan. Hal ini sejalan dengan pendapat Nasution (1996: 74) yang mengatakan bahwa wawancara dapat dilakukan melalui tiga pendekatan, yakni: (l) dalam bentuk percakapan informal, yang mengandung unsur spontanitas, kesantaian, tanpa pola atau arah yang ditentukan sebelumnya, (2) menggunakan lembaran berisi garis besar pokok-pokok, topik atau masalah yang dijadikan pegangan dalam pembicaraan, dan (3) menggunakan daftar pertanyaan yang lebih terinci, namun bersifat terbuka yang telah dipersiapkan lebih dahulu dan akan diajukan menurut urutan dan rumusan yang tercantum.

Dokumen yang digunakan dalam penelitian ini foto-foto kegiatan dan formulir peserta meditasi kesadaran yang memuat berbagai informasi mengenai keterlibatan informan pada aktivitas meditasi. Penggunaan dokumen sebagai alat pengumpulan data dilakukan karena alasan bahwa dokumen merupakan sumber data yang stabil dan kaya informasi. Dokumentasi digunakan dalam penelitian sebagai sumber data karena dalam banyak hal dokumen sebagai sumber data dapat dimanfaatkan untuk menguji, menafsirkan, bahkan untuk meramalkan.

Cara yang digunakan untuk memeriksa keabsahan data dalam penelitian ini adalah dengan menguji kredibilitas data, yang meliputi perpanjangan pengamatan, peningkatan ketekunan, triangulasi, diskusi dengan teman, analisis kasus negatif, dan member check; transferability; dependability; dan confirmability (Sugiyono, 2007: 121). Perpanjangan pengamatan dilakukan agar hubungan peneliti dengan informan semakin akrab, tidak berjarak, terbuka, saling mempercayai sehingga tidak ada informasi yang disembunyikan. Perpanjangan pengamatan dilakukan untuk mendapatkan kedalaman, keluasan, dan kepastian data mengenai pelaksanaan meditasi kesadaran di Wihara Mendut.

Peningkatan ketekunan dilakukan dengan pengamatan secara lebih cermat dan berkesinambungan. Melalui peningkatan ketekunan ini, kepastian data dan urutan peristiwa akan direkam secara pasti dan sistematis. Peningkatan ketekunan dalam penelitian ini dilakukan dengan mengamati secara sistematis melalui observasi deskriptif, kemudian dilanjutkan observasi terfokus, dan diakhiri dengan observasi selektif. Observasi deskriptif dilakukan dengan mengamati lingkungan Wihara Mendut secara keseluruhan. Observasi terfokus diarahkan pada pengamatan tentang lokus dan fokus penelitian yang menjadi kajian dalam penelitian. Observasi selektif dilakukan untuk mengamati aktivitas informan saat melakukan meditasi kesadaran.

Triangulasi merupakan qualitative cross-validation, artinya pengecekan data dari berbagai sumber dengan berbagai cara dan waktu. Pengecekan data dalam penelitian ini dilakukan melalui triangulasi antarmetode, antarsumber, dan antarwaktu. Triangulasi antarmetode dilakukan dengan mencocokkan data berupa aktivitas informan peserta meditasi kesadaran, dokumen 
formulir peserta, dan perilaku peserta meditasi kesadaran yang diperoleh dari pengamatan maupun wawancara dengan sumber dokumen. Triangulasi antarsumber dilakukan untuk mencocokkan data yang diperoleh dari peserta meditasi kesadaran dengan yang didapat dari penyelenggara, demikian juga sebaliknya. Triangulasi antarwaktu dilakukan untuk mencocokkan data yang diperoleh dengan wawancara yang dilakukan beberapa kali dengan waktu yang berbeda.

Analisis kasus negatif terutama dilakukan jika ada data yang tidak sesuai atau berbeda dengan hasil penelitian hingga saat tertentu. Peneliti mencari data yang berbeda atau bahkan bertentangan dengan data yang ditemukan. Bila tidak ada lagi data yang berbeda atau bertentangan dengan temuan, berarti data yang ditemukan sudah dapat dipercaya. Analisis kasus negatif ditempuh jika ada data yang berhubungan dengan makna meditasi kesadaran bagi peserta retreat dari lapangan yang tidak sesuai atau bertentangan dengan dokumen, maka peneliti meminta konfirmasi kepada informan dan/atau mengubah hasil temuan penelitian.

Menggunakan bahan referensi merujuk pada adanya pendukung untuk membuktikan data yang telah ditemukan oleh peneliti. Peneliti merekam wawancara yang akan ditranskrip sebagai bukti adanya bahan referensi mengenai data yang dimaksud, di samping dukungan berupa foto-foto. Dokumen otentik berupa transkrip wawancara, deskripsi hasil observasi, foto-foto kegiatan yang berkorelasi dengan arah temuan penelitian tentang pelaksanaan meditasi kesadaran dan maknanya bagi peserta non-Buddhis disertakan dalam lampiran penelitian ini untuk mendukung kredibilitas data.

Member check merupakan proses pengecekan data yang diperoleh peneliti kepada pemberi data, di antaranya peserta dan penyelenggara meditasi kesadaran. Informan sebagai pemberi data diminta untuk membaca transkrip wawancara dan deskripsi hasil observasi; kemudian membubuhkan paraf di setiap lembarnya untuk meyakinkan bahwa data yang diberikan sesuai dengan maksud informan. Jika data yang ditemukan disepakati oleh informan, maka data tersebut valid, sehingga semakin kredibel dan dipercaya; tetapi apabila data yang ditemukan peneliti dengan berbagai penafsirannya tidak disepakati oleh informan atau perbedaannya tajam, maka peneliti mengubah temuannya dan menyesuaikan dengan apa yang diberikan oleh informan.

Pengujian transferability merujuk pada sejauh mana hasil penelitian dapat diterapkan atau digunakan dalam situasi lain. Untuk memenuhi uji transferabilitas ini peneliti berusaha agar hasil penelitian dipahami oleh orang lain dengan membuat laporannya rinci, jelas, sistematis, dan dapat dipercaya. Dengan demikian, orang lain menjadi jelas atas hasil penelitian ini, sehingga dapat memutuskan dapat atau tidaknya mengaplikasikan hasil penelitian tersebut pada situasi lain.

Pengujian dependability setara dengan reliabilitas pada penelitian kuantitatif. Pengujian dependabilitas dilakukan dengan melakukan audit 
terhadap keseluruhan proses penelitian. Pada penelitian ini, pengujian dependabilitas dilakukan oleh Ketua Jurusan sebagai auditor independen yang menilai proses penelitian ini mulai dari penentuan masalah atau fokus, memasuki lapangan, menentukan sumber data, melakukan analisis data, melakukan uji keabsahan data, sampai membuat kesimpulan. Pengujian dependabilitas pada dasarnya untuk mengetahui jejak aktivitas lapangan peneliti.

Pengujian confirmability mencerminkan objektivitas penelitian. Menguji objektivitas penelitian dilakukan dengan cara menguji hasil penelitian yang dikaitkan dengan proses yang dilakukan. Hasil penelitian sebagai fungsi proses penelitian yang dilakukan, sehingga penelitian tersebut telah memenuhi standar konfirmabilitas. Dengan demikian, pada penelitian ini pengujian konfirmabilitas dilakukan bersamaan dengan uji dependabilitas. Proses penelitian ini menggunakan analisis data model Miles \& Huberman yang meliputi tahapan: pengumpulan data, reduksi data, penyajian data, dan penarikan simpulan.

\section{Hasil dan Pembahasan}

Wihara Mendut terletak di wilayah administratif Kecamatan Mungkid, Kabupaten Magelang, Jawa Tengah. Wihara Mendut merupakan salah satu aset penting di bawah binaan sebuah organisasi besar keagamaan yaitu Sangha Theravada Indonesia. Wihara Mendut menjadi tujuan wisata religius yang ditetapkan oleh Pemerintah Kabupaten Magelang, di samping tempat-tempat besar lainnya, di antaranya Candi Borobudur, Gereja Ayam, serta beberapa pondok pesantren.

Kompleks Wihara Mendut terdiri dari beberapa bangunan yang memiliki nilai fungsional sesuai dengan namanya, di antaranya gedung dhammasala, serbaguna, basement, wisma penginapan, dan kuti. Gedung-gedung di kompleks Wihara Mendut dapat digunakan di luar fungsinya jika sedang diselenggarakan suatu acara. Keberadaan Wihara Mendut yang memiliki luas kurang lebih satu hektar menjadi pusat kegiatan yang diselenggarakan oleh berbagai organisasi sosial keagamaan, baik tingkat lokal maupun nasional, bahkan internasional.

Penyelenggaraan Meditasi Kesadaran di Wihara Mendut menggunakan hampir seluruh bangunan dan area yang ada. Peserta meditasi mulai datang biasanya melakukan registrasi ulang di gedung bagian belakang yang digunakan untuk penginapan. Peserta yang sudah selesai registrasi ditunjukkan oleh petugas di mana harus meletakkan barang pribadi yang sekaligus sebagai tempat tidur selama retret. Di samping itu, peserta juga ditunjukkan toilet dan pantry sederhana oleh petugas yang terletak di bagian belakang gedung penginapan dan bisa digunakan oleh semua peserta.

Menjelang pukul tujuh malam, petugas membunyikan bel atau lonceng kecil sebagai tanda akan dimulainya retret. Peserta, petugas, kepala wihara, guru pembimbing memasuki ruang gedung dhammasala bagian belakang. 
Gedung dhammasala belakang ini digunakan sebagai ruang pertemuan utama selama retret berlangsung. Ruangan sudah diatur sedemikian rupa dengan bantal khusus duduk bermeditasi yang terbagi ke dalam dua kelompok sesuai jenis kelamin peserta. Gedung dhammasala ini memiliki area luas di sekitar bangunan yang dapat digunakan oleh peserta untuk meditasi jalan atau duduk di ruang terbuka.

Pada dasarnya, peserta meditasi dapat menggunakan seluruh area dan gedung serta fasilitas yang ada di kompleks wihara untuk berpraktik meditasi sesuai instruksi pembimbing. Kompleks wihara ditutup bagi pengunjung lain yang akan berwisata selama pelaksanaan retret untuk memberi suasana kondusif bagi peserta. Peserta meditasi menggunakan seluruh area yang ada selama masih berada di dalam kompleks dan tidak melewati batas tanda yang sudah ditentukan oleh pihak penyelenggara. Titik-titik atau lokasi maupun gedung dan fasilitas yang dapat digunakan selama berpraktik meditasi dengan berbagai postur, di antaranya stupa, serbaguna, gazebo, wisma penginapan, teras penginapan, dan berbagai ruang lapang di seluruh kompleks. Ruang perpustakaan tidak disarankan untuk digunakan bermeditasi karena memicu aktivitas membaca dari peserta yang cenderung mengganggu latihan meditasi yang menekankan pada pengamatan ke dalam atas fenomena batin dan fisik peserta itu sendiri.

Fokus penelitian diturunkan dari pertanyaan penelitian sebagai elemen penting pada terjawabnya rumusan masalah yang menjadi tujuan penelitian. Fokus penelitian ini adalah relevansi meditasi dengan permasalahan kehidupan, dampak meditasi bagi kehidupan sehari-hari, serta pandangan tentang keberagaman peserta terutama yang mengarah pada spiritualitas dan kehidupan. Tiga fokus ini dipandang mampu menjawab rumusan permasalahan yang ditetapkan yaitu tentang keharmonisan dalam keberagaman pada komunitas Meditasi Kesadaran di Wihara Mendut. Keharmonisan menjadi cita-cita yang harus diwujudkan dalam masyarakat plural dan multi. Di sisi lain, keberagaman dari berbagai segi memiliki potensi destruktif jika tidak dikelola dengan baik. Dengan demikian, pandangan dan makna yang dimiliki seseorang mengenai spiritualitas yang beragam, baik sebagai sebab maupun akibat mengikuti retret meditasi merupakan konsekuensi logis pada upaya pemahaman antarmanusia pada tingkat yang lebih luas dalam mengenal diri dan sosialnya yang bisa jadi turut membangun peradaban dan keharmonisan dunia.

Data penelitian dikumpulkan melalui wawancara, observasi, dan dokumentasi untuk mengarah pada terjawabnya pertanyaan penelitian yang dilabeli sebagai fokus penelitian yang telah ditetapkan sebelumnya. Relevansi meditasi dengan permasalahan kehidupan yang dialami oleh peserta terbagi dalam beberapa tema, yaitu awal mengenal meditasi, perbandingan antarguru meditasi yang pernah diikuti, masa-masa pencarian spiritual, awal mengenal meditasi yang lebih spesifik karena mengalami masalah kehidupan, pengidentifikasian pada masalah yang dihadapi dan pengetahuan meditasi 
yang diperoleh, serta pentingnya pihak penyelenggara sebagai bagian dari latihan meditasi yang diikuti. Dampak meditasi dalam kehidupan sehari-hari bagi peserta memiliki keterkaitan dengan tema bentuk, waktu, dan jadwal latihan; cara menanggapi situasi pada level biasa maupun yang lebih tinggi; kesadaran atas syarat yang diperlukan untuk berlatih, serta makna dan pentingnya hasil yang diperoleh setelah latihan. Pandangan yang mengarah pada makna keberagaman peserta meditasi dapat dikenali dari tema-tema yang menjadi temuan penelitian, yaitu ketaatan pada aturan yang ditetapkan penyelenggara, sikap terhadap sesama peserta, pandangan mengenai agama atau spiritualitas antarpeserta, hakikat keberagaman, dan keberlanjutan komunitas di luar sesi retret periodik.

Peserta mengenal meditasi dalam kurun waktu yang cukup lama mulai dari tahun 1995 hingga yang paling baru yaitu tahun 2018. Perkenalan dengan meditasi berawal dari informasi yang diperoleh dari teman, media, website, membaca buku, dan googling. Guru pembimbing mulai mengajar meditasi setelah pulang ke Indonesia dari studi di luar negeri. Banyak peserta yang mengenal meditasi dari teman atau kolega setelah terlibat pembicaraan mengenai tema spesifik, seperti kematian dan pencarian kebahagiaan. Bahkan, di awal perkenalan dengan meditasi muncul kebingungan karena teknik yang dipelajari benar-benar baru bagi sebagian peserta, yaitu langsung mengamati dan persepsi atas pemahaman ajaran Buddhis yang dimiliki sebelumnya hingga pembuktian keterlibatan pada berbagai retret hingga muncul rasa percaya.

Komunitas Meditasi Kesadaran di Wihara Mendut berasal dari berbagai latar belakang dalam hal kepemilikan pengetahuan dan pengalaman pada retret serupa dengan guru pembimbing yang berbeda. Peserta telah mengikuti berbagai retret, baik di dalam negeri maupun luar negeri, yaitu di Malang, Blitar, Bogor, Klaten, Yogyakarta, dan Prancis. Perbandingan cara, metode, teknik, maupun persepsi peserta mengenai keragaman guru yang pernah mengajar meditasi, di antaranya lebih ilmiah, menjelaskan proses pikiran, to the point pada apa yang harus dilakukan, penjelasan dari sisi Buddhis, menggunakan bahasa sederhana, terinspirasi dengan seorang biku yang menjelaskan tentang winaya larangan merusak pohon, laku keras duduk lama berjam-jam pada teknik tertentu, penamaan khusus sebagai ciri khas guru tertentu (silent illumination, meditasi tanpa objek, meditasi bertahap, meditasi Plum Village). Teknik silent illumination dikenalkan oleh guru meditasi Zen bernama Master Cheng Yen, meditasi bertahap oleh Bhikkhu Kantidharo Mahathera, teknik meditasi dari Plum Village di Prancis oleh Thich Nath Hanh, dan meditasi tanpa objek dipopulerkan oleh seorang rohaniwan Katolik bernama Romo Sudrijanta.

Tahap pencarian spiritual hingga bertemu dengan komunitas Meditasi Kesadaran di Wihara Mendut dari peserta beraneka ragam mulai dari mencoba-coba di banyak tempat, guru, maupun merasakan berpindah dari agama satu ke agama lainnya. Pertemuan peserta dengan komunitas Meditasi 
Kesadaran menjadikan latihan hidup berkesadaran sebagai proses yang harus dijalankan sebagai konsekuensi atas pencariannya selama ini, walaupun mereka mengaku belum bisa langsung ke level sadar dan memerlukan latihan terus-menerus sebelum mampu secara otomatis. Peserta mengalami sejumlah permasalahan kehidupan hingga akhirnya bertemu dengan konsep meditasi dan komunitasnya yang dianggap mampu meringankan atau bahkan menyelesaikan masalah-masalah yang dialami. Dalam konteks ini, meditasi dianggap mampu membawa ketenangan di saat menghadapi situasi dan posisi sulit, bahkan saat menghilangkan trauma akibat kekerasan seksual.

Peserta mengidentifikasi permasalahan dalam praktik meditasi kesadaran mulai dari yang bersifat materi yang tidak dapat lepas dari handphone hingga kesulitan dalam membendung munculnya emosi-emosi negatif. Emosi batin yang cenderung negatif mendominasi pengalaman meditasi peserta yang dianggap sebagai kegagalan praktik. Emosi-emosi negatif yang diidentifikasi sebagai permasalahan dalam meditasi, baik pada saat retret maupun praktik keseharian yaitu mudah panik, masih melekat pada sesuatu atau seseorang, ego masih tinggi, tidak dianggap, terikat dengan masa depan, merasa ribut dengan pikiran sendiri, merasa rugi dengan masa lalu. Di sisi lain, peserta juga mendapatkan solusi atas permasalahan meditasi yang sedang dihadapi dengan munculnya insight, yaitu pemahaman bahwa kekecewaan dan rasa penyelasan berkurang, sabar, menyadari kehalusan pikiran, menutupi dukkha dengan kesenangan sementara, hingga pada menyadari keberadaan permasalahan halus yang dianggap telah hilang.

Komunitas Meditasi Kesadaran saling tahu dan terbiasa dengan jargon istilah yang sering digunakan pada konteks meditasi vipassana. Bentuk praktik meditasi kesadaran dipahami sebagai hal yang relatif sama dengan doa hening pada agama Kristen dan merupakan istilah yang saling dapat dipertukarkan dengan vipassana. Meditasi kesadaran tidak menjanjikan manfaat spontan, radikal, dan duniawi. Praktik meditasi kesadaran berarti menyadari mental, pikiran, emosi, dan fisik sekaligus, baik yang menyenangkan maupun tidak menyenangkan. Meditasi kesadaran tidak bertujuan untuk mencapai ketenangan, melainkan untuk melepaskan sesuatu dengan menggunakan kesadaran sebagai instrumen untuk mengamatinya. Ketenangan sebagai fenomena yang berubah dikenali melalui alat kesadaran yang mampu melihat dengan objektif dan tajam. Batin yang mencari ketenangan justru akan memunculkan kemelekatan sebagai sebab penderitaan (dukkha). Meditasi kesadaran atau vipassana menghasilkan pemahaman dukkha secara menyeluruh sebagaimana adanya yang mampu menjernihkan batin tanpa terlibat dengan fenomena. Jargon yang paling dipahami secara kontekstual pada praktik meditasi kesadaran yaitu sadar, sekadar sadar, dan menyadari.

Peserta meditasi memiliki sejumlah harapan kepada penyelenggara agar retret yang dilakukan memiliki relevansi kuat dengan permasalahan kehidupan. Peserta meditasi menginginkan kohesivitas antarpeserta 
dibangun dalam rangka mengenal satu sama lain, di samping untuk berbagi pengalaman yang ada kaitannya dengan dampak meditasi dalam kehidupan sehari-hari. Penyelenggara menyadari keresahan beberapa peserta yang mendapatkan nama retret ini dengan sebutan Meditasi Kesadaran, bukan vipassana sebagaimana yang telah dikenal selama ini. Penamaan khusus ini tidak bermaksud menjadikan eksklusif komunitas ini tetapi lebih pada pengenalan meditasi kepada masyarakat luas tanpa terikat formalitas agama Buddha. Pada intinya, penyelenggara menginginkan pelaksanaan meditasi kesadaran atau vipassana ini berlangsung kondusif tanpa terbelenggu pada peristilahan dan konseptual semata.

Bentuk latihan peserta meditasi berpusat pada jargonnya, yaitu latihan mengamati tiap hari, baik duduk formal maupun aktivitas keseharian. Bentuk latihan ini cenderung tidak tergantung pada waktu dan keadaan, walaupun lebih banyak melihat keluar diri daripada mengamati ke dalam batin. Proses latihan mengamati dapat dilakukan pada saat peserta menjalani aktivitas sehari-hari, misalnya adalah mencuci piring. Kegiatan mencuci piring dapat dilakukan dengan penuh kesadaran dengan cara mengamati sebagaimana adanya proses yang sedang berlangsung. Jadwal latihan bervariasi yang blangblong, rutin, maupun pada hari-hari tertentu di wihara. Waktu yang dibutuhkan peserta untuk bermeditasi sekitar lima belas menit, yang dilakukan menjelang tidur, pada saat di dalam bus ketika mengadakan perjalanan, atau bahkan saat membuat renda yang membutuhkan ketekunan dan ketelitian.

Peserta merasakan cara menanggapi situasi dengan cara berbeda setelah mengenal dan mengikuti retret meditasi. Meditasi kesadaran menjadikan seseorang lebih awas mengawasi gerak pikiran, mendukung praktik sīla. Pembimbing sebagai guru yang mengajar meditasi memiliki perlakuan khusus sebagai dampak keberagaman peserta dari berbagai latar belakang orientasi spiritual. Pembimbing menggunakan sutta-sutta (rujukan khotbah Buddha) ketika menjelaskan materi saat jam diskusi. Hal ini dilakukan jika peserta lebih banyak yang Buddhis, sedangkan jika sebaliknya pembimbing menggunakan istilah umum yang dicarikan sendiri padanannya agar mudah dipahami. Materi-materi yang didiskusikan saat retret meditasi kesadaran, yaitu sati, lima rintangan batin, dukkha, dan konsep aku.

Peserta meditasi sebagian besar merupakan peserta lama yang telah mengikuti retret berkali-kali. Hal ini diprediksi memiliki pengaruh besar dalam memahami meditasi dan dampaknya bagi kehidupan sehari-hari. Pemahaman peserta lama menggugah kesadaran mengenai hidup itu sendiri dan cenderung tidak melekat. Praktik meditasi dapat membuat seseorang melepas banyak emosi negatif dan mendapatkan sesuatu yang dapat disebut sebagai insight. Peserta memahami bahwa segala sesuatu tergantung pada persepsi tiap diri. Persepsi mampu mengubah segala hal, termasuk pandangan seseorag dalam menanggapi permasalahan dalam kehidupan. Kehidupan dengan segala permasalahannya dijalani dengan menerima apa adanya dengan 
berlatih hidup berkesadaran setiap saat serta eling lan waspada. Perkenalan peserta dengan meditasi dianggap sebagai berkah besar dan merasa sebagai orang pilihan. Dengan kata lain, mengenal meditasi kesadaran merupakan perjalanan panjang yang patut disyukuri sebagai orang-orang pilihan yang mengenal cara langsung dalam merealisasi kebebasan.

Pengalaman peserta menunjukkan bahwa meditasi memerlukan syarat tertentu. Meditasi ada kaitannya dengan praktik sīla karena muncul perasaan tidak enak jika peserta melanggarnya. Meditasi kesadaran tidak perlu dijelaskan dengan banyak teori, tetapi harus dipraktikkan langsung. Pada waktu tertentu peserta menjalankan atthasīla untuk mendukung praktik meditasi lebih baik. Hal ini dilakukan karena pemahaman meditasi diperlukan banyak praktik dibandingkan belajar teoretik. Latihan meditasi kesadaran lebih banyak melihat ke dalam dibandingkan merespons dan menanggapi stimulus dari luar diri. Pemahaman dan latihan praktik langsung perlu dilakukan berkali-kali bahkan setiap saat yang perlu menghadirkan seseorang untuk membimbing. Latihan meditasi kesadaran tidak sekadar duduk formal bermeditasi dengan sikap kaku, tetapi lebih pada menghadirkan kesadaran dalam kehidupan sehari-hari. Dengan kata lain, setiap aktivitas keseharian merupakan sarana untuk berlatih menajamkan kesadaran seseorang.

Peneliti memiliki pemaknaan terhadap dampak besar yang dihasilkan setelah seseorang aktif bermeditasi. Makna ini dapat diketahui bahkan sebelum seseorang terlibat dalam latihan praktik dengan mengandalkan pemahaman secara teoretik. Retret meditasi dilakukan peserta sebagai recharge energi dengan keadaan batin yang lebih segar dan mencerahkan. Pengalaman meditasi dipandang sebagai bekal yang harus dimiliki oleh seseorang jika akan melakukan pendampingan psikologi seseorang lainnya. Secara psikologis, seseorang yang bermeditasi akan memiliki kepribadian solid yang mampu menghadapi segala persoalan kehidupan. Permasalahan kehidupan secara normatif memang perlu diselesaikan, namun dengan melihat ke dalam dapat dikatakan 50\% sudah dapat diselesaikan. Aktivitas keseharian sebagai bagian yang tidak dapat dipisahkan untuk menjaga kesadaran dengan penuh kesabaran dalam setiap tindakan.

Retret meditasi diselingi dengan diskusi yang membahas tentang materi-materi yang berkenaan dengan tema kesadaran. Peserta mendengarkan dan mengajukan pertanyaan mengenai materi yang sedang didiskusikan dan/atau berdasarkan pengalaman peserta yang bersangkutan. Penjelasan guru pembimbing ada yang dipahami dan ada yang tidak dipahami karena tidak semua orang mudah memahami tanpa pengalaman atau perenungan mendalam. Hasil yang dirasakan setelah lama ikut retret secara periodik dalam hal fisik yaitu peserta lebih cantik, tidak pemarah lagi, sensitif, nyaman, tidak ada dendam, enjoy, cool. Hasil meditasi dari sisi mental dapat dikenali oleh peserta dengan merasakan perubahan diri masing-masing melalui pengamatan dari batin yang tidak bergemuruh, mampu berpikir 
bening, dan lebih arif. Kunci dari meditasi kesadaran telah dipahami secara intelektual oleh peserta dan harus terus dilatih dalam bentuk praktik, yaitu tidak menyalahkan objek luar diri sehingga masalah dapat diselesaikan begitu menyadari batin. Peserta menyadari bahwa insight seperti ini mampu mengubah masyarakat yang lebih damai. Dengan kata lain, perubahan sosial dimulai dari transformasi diri sendiri dengan menyadari batin setiap saat.

Fokus penelitian pandangan peserta meditasi terhadap keberagaman menjadi tema sentral kajian ini. Pandangan komunitas tentang keberagaman menjadi dasar munculnya sikap batin dalam laku hidup spiritual dalam kehidupan sehari-hari. Peserta mentaati peraturan yang ditetapkan oleh penyelenggara, di antaranya tidak diperbolehkan berbicara sesama peserta selama pelatihan berlangsung (noble silent). Peserta Buddhis dipandang kurang taat pada peraturan ini disbanding peserta non-Buddhis. Peserta banyak yang mencatat hasil diskusi walaupun aktivitas ini tidak disarankan oleh pembimbing maupun penyelenggara. jika ada peserta yang melakukan pelangaran terhadap peraturan atau bertingkah laku yang sekiranya mengganggu, peserta lain cenderung maklum dan tidak mempermasalahkan hal kecil tersebut. Beberapa peserta sudah saling mengenal karena sering bertemu di berbagai komunitas meditasi lainnya, baik satu kota maupun antarkota. Antarpeserta saling mencurahkan pengalaman masing-masing, baik tentang meditasi maupun kehidupan yang cenderung mengganggu jika dilakukan saat mengikuti retret. Namun demikian, di sisi lain peserta juga saling memahami jika bertemu peserta yang dianggap sebagai "wong edan" karena cerita dan pengalamannya yang sangat ekstrem walaupun sangat dipahami.

Keberagaman dimaknai oleh peserta dengan ditandai sikap dan pandangannya terhadap agama lain. Banyak peserta yang membandingkan konsep meditasi yang sedang dijalankan saat retret dengan ajaran agama yang dianutnya. Agama yang tertulis di Kartu Tanda Penduduk (KTP) peserta tidak menjadi persoalan dalam berlatih meditasi. Walaupun memeluk agama tertentu tetapi peserta menjadikan meditasi kesadaran sebagai laku hidup keseharian. Ajaran-ajaran pendukung pelaksanaan meditasi dijadikan dasar dalam memperlakukan orang beragama lain, di antaranya konsep tidak memunculkan kebencian bahkan terhadap orang jahat sekalipun. Meditasi kesadaran membuat peserta lebih peka dalam bersosialisasi dengan sesama. Dengan demikian, intoleransi menjadi hal yang dianggap sebagai kebodohan batin.

Hakikat keberagaman spiritualitas komunitas Meditasi Kesadaran di Wihara Mendut dalam konteks praktik dipandang sebagai hal universal. Pada konteks pengenalan diri, setiap individu pada dasarnya sama dalam mencapai kebahagiaan dan tidak ingin menderita serta tidak merugikan secara sosial. Keberagaman dipandang sebagai dasar penguatan multikulturalisme antarpeserta. Pemahaman terhadap keberagaman merupakan unsur penting untuk saling mengenal agar lebih ikhlas menerima. 
Harmonisasi dalam keberagaman komunitas Meditasi Kesadaran berlanjut hingga di luar retret dalam bentuk diskusi tentang masalah pribadi maupun pengalaman meditatif, baik bertemu langsung maupun melalui media sosial Facebook. Beberapa peserta dapat konsultasi langsung kepada guru pembimbing melalui media sosial atau pesan singkat. Namun demikian, banyak peserta yang putus komunikasi setelah retret berakhir karena tidak saling mengenal, tidak saling mendukung, dan tidak selalu berteman.

\section{Kesimpulan}

Kesimpulan penelitian ini adalah: (a) relevansi meditasi dengan permasalahan kehidupan bagi peserta retret meditasi kesadaran di Wihara Mendut berkaitan erat dengan permulaan peserta mengenal meditasi, perbandingan antarguru, tahapan pencarian, kemampuan mengidentifikasi permasalahan kehidupan dan problematika dalam mengikuti meditasi kesadaran, dan saran bagi penyelenggara dalam mendukung pelaksanaan meditasi; (b) dampak meditasi dalam kehidupan sehari-hari bagi peserta retret meliputi bentuk latihan, jadwal dan waktu latihan, cara menanggapi situasi, pemahaman yang lebih tinggi dalam meditasi kesadaran, persyaratan berlatih, makna dampak bagi peserta, dan hasil meditasi; dan (c) pandangan peserta retret meditasi kesadaran memiliki kaitan erat dengan ketaatan dalam mengikuti retret, hubungan sesama peserta, cara pandang terhadap agama lain, hakikat keberagaman, dan keberlanjutan komunitas di masa mendatang.

\section{Daftar Pustaka}

Analayo. 2010. Satipatthāna: The Direct Path to Realization. Cambridge: Windhorse Publications.

Dadang Kahmad. 2009. Sosiologi Agama. Bandung: Remaja Rosdakarya.

Goldstein, Joseph. 2013. Mindfulness: A Practical Guide to Awakening. Boulder, Colorado: Sounds True.

Harmilah, Elly Nurachmah, \& Dewi Gayatri. 2011. Penurunan Stres Fisik dan Psikososial Melalui Meditasi pada Lansia dengan Hipertensi Primer. Jurnal Keperawatan Indonesia. Volume 14, Nomor 1, Maret 2011, 57-64.

Jalaluddin. 2016. Psikologi Agama: Memahami Perilaku dengan Mengaplikasikan Prinsip-Prinsip Psikologi. Jakarta: RajaGrafindo Persada.

Kumbang Sigit Priyoaji. 2017. Bimbingan Meditasi Zen dan Implikasinya terhadap Kesehatan Mental: Studi atas Kelompok Meditasi Zen di Wihara Buddha Prabha Gondomanan Yogyakarta. Skripsi. Yogyakarta: Program Studi Agama-Agama, Fakultas Ushuludin dan Pemikiran Islam, Universitas Islam Negeri Sunan Kalijaga.

Komaruddin Hidayat. 2008. The Wisdom of Life: Menjawab Kegelisahan Hidup dan Agama. Jakarta: Kompas. 
Sekar Ayu Aryani. 2015. Orientasi, Sikap, dan Perilaku Keagamaan: Studi Kasus Mahasiswa Salah Satu Perguruan Tinggi Negeri di DIY. Religi. Volume XI, Nomor 1, Januari 2015, 59-80.

Sudrijanta, J. 2013. Pencerahan. Yogyakarta: Kanisius.

Sujiva, Venerable. 2000. Essentials of Insight Meditation Practice: A Pracmatic Approach to Vipassana. Petaling Jaya, Selangor: Buddhist Wisdom Centre. 